\title{
"Interpreter[s] of Maladies:" A Study of Some Selected Short Stories by Ahdaf Soueif and Jhumpa Lahiri
}

\author{
by
}

Dr. Waleed Samir Ali

Lecturer in English Literature

Faculty of Education, Tanta University 


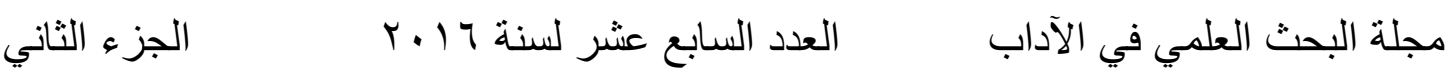

\section{"Interpreter[s] of Maladies:" A Study of Some Selected Short Stories by Ahdaf Soueif and Jhumpa Lahiri}

In their short stories, both Ahdaf Soueif and Jhumpa Lahiri are preoccupied with representing the complexity of cultural encounters which are seen as a catalyst of identity formation as well as cultural hybridization. Their works of fiction show how identity is formed through mutual cultural translation in a world that is generally transcultural. The characters representing cultural encounters do not only assimilate or adopt the dominant culture of ex-colonizing society, but they manage to develop their own native culture and blend it with the mainstream one to fulfill their dreams. Such "blending" of cultures is, according to Welsch, a major feature of contemporary culture. He argues that

the deep differences between cultures are today diminishing more and more, that contemporary cultures are characterized by cross-culturing elements - and in this sense are to be comprehended as transcultural rather than monocultural. (3)

The term "transculturation" was first coined by Fernando Ortiz who stresses the significance of human beings as representatives and bearers of culture, hence the fusing and synthesizing nature of culture. Welsch's concept of transculturation, on the other hand, is based on the presumption of "commonalities" (12) among various world cultures, unlike the old colonial concept that relies on separatist and essentialist ones. Welsch maintains that

transcultural intersections lead to an initial acquisition of commonalities, and the possession of these consequently enables further acquisitions. This increased possibility for exchange and coming to term with each other obviously represents a great advantage in transcultural constitution. (13)

Therefore, it is necessary to enhance cultural commonalities instead of fostering differences to avoid the clash of cultures.

In addition, it is important to acknowledge the effect of differing cultures in the process of identity formation, a fact that is supported by Said's view: "all cultures are involved in one another; none is single and pure, all are hybrid, heterogeneous, extraordinary differentiated, and unmonolithic"(Culture and Imperialism xxv). Cultural encounters entail 


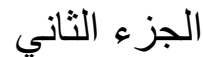

cultural exchange which, in turn, provides a chance for a better communication among the members of different cultures involved in that process. Welz explains that "cultural barriers are much more difficult to fix, let alone map on to territorial divides, as communication channels transgress and migrant communities routinely cross them" (38).

Shedding light on the unique nature of transculturation, Sommer argues that it

ascribes a positive connotation to cultural hybridity, cosmopolitan globalisation and ethnic fragmentation while establishing them as counter models to exclusively national or ethnic identities. Therefore transcultural concepts are marked by a utopia moment: they develop optimistic counter approaches to the 'classic' models of multicultural assimilation and alteration to the extent of approaching visions of dissolution of fixed cultural identities. (qtd. in Sissy Helff, "Shifting Perspectives: The Transcultural Novel" 80)

Sales adds:

transculturation, the in-between third space, emerges as a productive way for the borderline experience of contact between cultures, both in life and in fiction, where the negotiation of differences, sometimes incommensurable, may create a complex tension that could also grow into a strategy of cultural survival: beyond polarizations, against the grain of the rhetoric of binarism, from a creative inbetween transcultural space of communicative bridging. (88)

Bhabha's "Third Space," Pratt's "Contact Zone" and Soueif's "Mezzaterra" embody the "utopia moment" suggested in Sommer's words. The three concepts reflect the attempts of the writers to overcome cultural differences. The short stories of both Soueif and Lahiri depict the cultural encounter experience. Their protagonists negotiate their identities to resolve cultural tensions in order to survive in a world of acute binarism.

Various theories have been proposed to approach cultural encounters and how they affect identity formation. Challenging colonial 
notions about fixed or essential identity, Hall argues that identity is strongly affected by history, culture and power. Therefore, it is in a perpetual process of change. Identity, for Hall, is a " "production' which is never complete, always in process, and always constituted within, not outside, representation" (222). He suggested two ways of thinking about cultural identity. The first one is static and fixed, while the second is in flux:

Cultural identity, in this second sense, is a matter of 'becoming' as well as 'being'. It belongs to the future as much as to the past. It is not something which already exists, transcending place, time, history and culture. Cultural identities come from somewhere, have histories. But like everything which is historical, they undergo constant transformation. (225)

Affected by Hall, Bhabha suggests hybridity as a means of approaching the Other. For Bhabha, the encounter of two different cultures involves the negotiation of identity which takes place in a "third space" and results in the hybridization and dissemination of both cultures. In this way, the new hybrid identity is formed by combining elements of both cultures. In "Cultural Diversity and Cultural Differences" (2006) Bhabha maintains:

It is that Third Space, though unrepresentable in itself, which constitutes the discursive conditions of enunciation that ensure that the meaning and symbols of culture have no primordial unity or fixity; that even the same signs can be appropriated, translated, rehistoricized, and read anew. (157)

It is through the "Third Space" that cultural differences can be articulated, resulting in an "international culture" which is based "not on the exoticism or multiculturalism of the diversity of cultures, but on the inscription and articulations of culture's hybridity" (157). The "Third Space" enables the immigrant to reconsider his native culture from a different perspective. Through perpetual interaction with the culture of the host society, the immigrant is able to form a third identity for himself which is different from both cultures in that it is a hybridization or blending of his native culture and that of the host society. In this way, Bhabha's "Third Space" deconstructs the colonial notion of fixed and essential identity. 
Soja takes Bhabha's "Third Space" concept further. According to Soja, Bhabha's "in-between" space "provide[s] the terrain for elaborating strategies of self-hood-singular or communal - that initiate [s] new signs of identity, and innovative sites of collaboration, and contestation, in the act of defining the idea of society itself' (143). Spatial beings by nature, Soja argues, we are involved in the social construction of space which is characterized by being an ever-changing and shifting "milieu of ideas, events, appearances and meanings" (2). It is an ideal place for cultural exchange. It is "a space where issues of race, class, and gender can be addressed simultaneously without privileging one over the other" (5).

In fact, Soja's "Spatial Space" recalls Said's "imaginative geography," which Said defines, in his seminal work Orientalism, as

the objective space of a house - its corners, corridors, cellar, rooms - is far less important than what poetically it is endowed with, which is usually a quality with an imaginative or figurative value we can name and feel; thus a house may be haunted or homelike, or prison like or magical. So space acquires emotional and even rational sense by a kind of poetic process, whereby the vacant or anonymous reaches of distance are converted into meaning for us here. (55)

The three critics, thus, regard the "third space" as the imaginative state of mind which is aroused by the immigrant's need to relate to a sense of intimacy and security in his/her new world. It is often associated with dreams of common shared human values which bring out self-fulfillment. Since it is "unrepresentable," as Bhabha argues, the "third space" remains restricted to the domain of mind within imaginative geographic boundaries. Similarly, Said suggests that the representation of the Orient has been strongly related to space and geography. In Culture and Imperialism, Said argues that we cannot be completely free from the struggle over geography, territory, space and place. Therefore, it is necessary for the immigrant to create and visualize a "third space" for himself, even if it exists in his mind, in the process of forming his own identity. The feeling of inhabiting such space is, therefore, essential in the construction of the immigrant's identity.

Like Bhabha, Pratt suggests a "contact zone" to perform cultural exchange. She defines the "Contact Zone" as "social spaces where cultures meet, clash, and grapple with each other often in asymmetrical relations of domination and subordination - such as colonialism and slavery, or their aftermaths as they are lived out across the globe today" 
(7). It refers to "the space of imperial encounters, the space in which peoples geographically and historically separated come into contact with each other and establish ongoing relations, usually involving conditions of coercion, radical inequality, and intractable conflict" (8). She perceives transculturation as a "phenomenon of the contact zone" (7). Childs and Williams argue that

by using the term 'contact,' Pratt wishes to replace narratives of conquest and domination with those of interaction, copresence, and shared practices. She calls the place that contact occurs a 'zone' because it is usually a space at the borders, initially, of one culture and the furthest reach of another. It is a site of compromise and resistance, assertion and imitation, hybridity and adaptation. (185)

In analyzing literary works, Pratt focuses on already established stereotypes of Western culture which shows the effect of colonial notions of fixed and essential identity on her. In other words, in the "contact zone" narratives, which Pratt calls "autoethnography," the dominants/ subordinate binary opposition is kept intact. Elucidating the nature of "autoethnographic" texts, Pratt, in "Arts of the Contact Zone"(1991), says:

Autoethnographic texts are not, then, what are usually thought of as an autochthonous forms of expression or selfrepresentation [...]. Rather, they involve a selective collaboration with and appropriation of idioms of the metropolis of the conqueror. These are merged or infiltrated to varying degrees with indigenous idioms to create selfrepresentations intended to intervene in metropolitan modes of understanding. (35)

Addressed to both subordinate and dominant readers, autoethnographic texts "constitute a marginalized group's point of entry into the dominant circuits of print culture" (35). Besides autoethnography, other literary forms flourish in the "Contact Zone" such as

transculturation, critique, collaboration, dialogue vernacular expression - these are some of the literary arts of the contact zone. Miscomprehension, incomprehension, dead letters, unread masterpieces, absolute heterogeneity of meaning these are some of the perils of writing in the contact zone. (Pratt "Arts of the Contact Zone" 37) 
Both Bhabha and Pratt, thus, acknowledge the binary opposition between Western and non-Western cultures which the immigrant tries to bridge and that is "unrepresentable." According to Bhabha, the "third space" is in a constant process of change, therefore, unattainable. The immigrant struggles to understand and change himself. Yet, he acknowledges the supremacy of the colonizer or the dominant culture. The Other, though involved in the process of cultural encounter, remains unaltered in the "contact zone." Thus, both the "third space" and the "contact zone" fail to resolve the tension of the Western/non-Western relationship or maintain mutual interaction between them. Rather, change is only done on the part of the immigrant without any suggestion that the Western individual is affected during the process of cultural interaction.

Soueif"s "Mezzaterra" attempts to resolve such tensions by creating a utopia that might be an alternative to the clash of cultures. The realization of the common ground/ "meeting point" between conflicting cultures enables the members of these cultures to bridge cultural barriers and co-exist happily. As a middle ground, the "Mezzaterra," unlike Bhabha's "Third Space" or Pratt's "Contact Zone," allows cultural encounter without one culture presiding over the other. Rather, "Mezzatera" supports exchange of cultures, knowledge and traditions between the Western and the non-Western disregarding power relations. Like Welsch's notion of existing commonalities among various people, Soueif's "mezzaterra" acknowledges the common affinities between East and West cultures that foster basic human values such as freedom, justice, equality and love of arts. What is unique about Soueif"s "mezzatera" is not only its utopian nature and claims but also its actual fulfillment and practice by Soueif's own generation during the Sixties. Describing this experience, Soueif, in Mezzaterra, says:

We were modern and experimental. We believed in Art and science. We cared passionately for Freedom and Social Justice. We saw ourselves as occupying a ground common to both Arab and Western culture, Russian culture was in there too, and Indian, and a lot of South America. (Mezzaterra 56)

The inhabitant of "mezzaterra," too, is not torn between his native culture/tradition and that of the host society. Acknowledging equality among human beings in general, he/she does not have to go through identity crisis. Soueif explains that "the question of identity as something that needed to be defined and defended did not occupy us. We were not looking inward at ourselves but outward at the world. We know who we were or thought we did" (Mezzaterra 6). Seeing "mezzaterra" a 
successful experience, Soueif considers the "Sixties identity as a spacious meeting point, a common ground with avenues into the rich hinter-lands of many traditions" (Mezzaterra 6).

What also contributes to the validity and authenticity of "mezzaterra" is that it was a practical and real experience that was not only practiced by Soueif's generation but also fulfilled by nineteenth century Arab thinkers. Soueif maintains that "mezzaterra"

was not invented or discovered by my generation. But we were the first to be born into it, to inhabit it as of right. It was a territory imagined, created, even, by Arab thinkers and reformers starting in the middle of the nineteenth century when Muhammed Ali Basha of Egypt, first sent students to the West and they came back inspired by the best of what they saw or offered. Generations of Arabs protected it through the dark time of colonialism. (Mezzaterra 6)

In addition, the human values endorsed by the inhabitants of "mezzaterra" were found in the Qur'an and the teachings of the Prophet. Cultural exchange was not only done on the part of the Arabs but also the West benefited from Arab civilization: "If science flourishes in the West now, it had flourished in the Arab and Muslim lands from the tenth to the fourteenth centuries" (Mezzaterra 7) which represented the peak of Arab civilization. In other words, history has long witnessed successful examples of cultural exchange between the West and the East. So, unlike Bhabha's "third space," which is "unrepresentable" and hence unattainable, Soueif's "mezzatera" is both representable and attainable as it shares the same universal values of the West, or as Soueif puts it:

This was the world that my generation believed we had inherited: a fertile land; an area of overlap, where one culture shaded into the other, where echoes and reflections added depth and perspective, where differences were interesting rather than threatening, because they were foregrounded against a backdrop of affinities. (Mezzaterra 7-8)

Soueif provides evidence that realizing and inhabiting "mezzaterra" is also rewarding:

At its best, it endows each thing at the same moment, with the shine of the new, the patina of the old; the language, the people, the landscape, the food of one culture constantly reflected off the other. This is not a process of comparison, not a 'which is better than which' project but rather at once a 
distillation and an enrichment of each thing, each idea. It means, for example, that you are both on the inside and the outside of language that within each culture your stance cannot help but be both critical and empathetic. (Mezzaterra 8)

"Mezzaterra," in this sense, is humanity's last resort to overcome cultural clashes, hence the necessity of protecting it:

In today's world, a separatist option does not exist, or version of this common ground is where we all finally, must live if we are to live at all. And yet the loudest voices are the ones that deny its very existence, that trumpet a 'clash of civilizations.' ( Mezzaterra 9)

The identity constructed in "mezzaterra" does not suffer from an inferiority complex. Rather it is enriched by the overlapping and interaction of cultures, merging finally as a cosmopolitan and humane identity, combining what is best of human values. Differences are reconciled and respected since the main focus is on shared commonalities. It is, therefore, necessary to reconsider the stereotypical notions of identity particularly in the new age of globalization, for, as Maalouf argues,

In the age of globalization and the ever accelerating intermingling of elements in which we are all caught up, a new concept of identity is needed, and needed urgently. We cannot be satisfied with forcing billions of bewildered human beings to choose between excessive assertion of their identity and the loss of their identity altogether, between fundamentalism and disintegration. (35)

The short stories of both Soueif and Lahiri probe the nature of identity in a transcultural world. Fixed and essential stereotypes of identity are deconstructed to illuminate the complexity of representing the experience of cultural encounter. The protagonists of their short stories attempt to negotiate their identities by creating/inhabiting a "third space"/"contact zone"/"mezzaterra." The short stories may be thus approached as transcultural narratives. According to Sales, transcultural narratives

exemplify and embody the complexity of cultural encounters, communicating differences and making visible their mediation process. They indeed create spaces for resistance, doubt, dialogue, and constant interaction, they preserve features from the cultures they live in-between, 
negotiating their differences from their transcultural worldview or experience. (86)

In addition, the transcultural novel, according to Helff, is distinguished by "its self-doubting characters, whose actions are dominated by uncertainty, a mind-set which thereby frequently influences the whole narrative" (82). Unlike intercultural narratives, the transcultural novel, Helff suggests, "introduces more radically individualized realities. A common imagined community is thus lost to the main protagonists, since transcultural characteristics challenge essentialist modes of identity construction" (82).

A study of the short stories of both Soueif (born 1950) and Lahiri (born 1967) reveals close affinities in terms of form, structure as well as thematic concerns. Moreover, both writers, like their protagonists, have gone through the cultural encounter experience as they are bilingual and bicultural. In addition, both use the English language as the main medium of their writings. However, they remain rooted in their native cultures. Soueif grows up as citizen of two worlds: Arabic and English. Commenting on Soueif's unique experience as a bilingual/bicultural writer, Said, in his review of Soueif's famous Aisha, says:

She writes, not as an Arabic novelist, but as an Egyptian whose literary language is English. Her companions in this enterprise are other post-colonials using English (as a worldlanguage) to reconstruct, revise and repossess experiences formerly either suppressed or denied them by colonialism. (n.p.)

She, in her writings, e.g. Mezzaterra, and several interviews celebrates her ability to bridge the cultural barriers distinguishing both worlds. Describing her bilingual/bicultural identity, Soueif says that she is "the product of a wrenched history: an Egyptian living in England and writing about Egypt in English" (Interview with Wassef n.p.). Describing Soueif's fiction, Said, in his review on Aisha, adds that her work is "not quite the product of a refugee mentality"(n.p.), for

Here we see a writer recovering episodes from a past lived in one society but haunting the present in a very different country, and expressed in a foreign language. [...]. Instead of politics we are given the strange dislocations that are caused by that unresolved tension between what is traditionally Muslim and Egyptian and what is Western and modern. (n.p.) 
The major theme in Souief's fiction, according to Said, in the same review, is "the transformation of the ideological, the political and the contemporary into the retrospective intensity of fetishes, rituals and fantasies framed by the biography of a woman neither entirely Arab nor entirely English" (n.p.).

Like Soueif, Lahiri felt herself under the pressure of being caught between two cultures. As a bicultural writer, Lahiri, in her Interview to Newsweek, recalls her early experience:

I have lived in the United States for almost 37 years and anticipate growing old in this country. Therefore, with the exception of my first two years in London, "IndianAmerican" has been a constant way to describe me. Less constant is my relationship to the term. When I was growing up in Rhode Island in the 1970s I felt neither Indian nor American. Like many immigrant offspring I felt intense pressure to be two things, loyal to the old world and fluent in the new, approved of on either side of the hyphen. Looking back, I see that this was generally the case. But my perception as a young girl was that I fell short at both ends, shuttling between two dimensions that had nothing to do with one another. (n.p.)

As a writer of two worlds, Lahiri, in the same interview, maintains :

When I first started writing I was not conscious that my subject was the Indian-American experience. What drew me to my craft was the desire to force the two worlds I occupied to mingle on the page as I was not brave enough, mature enough to allow in life. (n.p.)

Illustrating the nature of the immigrant's experience, Lahiri states in the same interview:

The immigrant's journey, no matter how ultimately rewarding, is founded on departure and deprivation, but it secures for the subsequent generation a sense of arrival and advantage. I can see a day coming when my American side, lacking the counterpoint Indian has until now maintained, begins to gain ascending and weight. (n.p.)

The protagonists of Souief and Lahiri, like their writers, are caught between two worlds. The short stories selected in this paper depict the protagonists' struggle to negotiate their identities in a transcultural world. As stories of initiation into the host society, they trace the success and 
sometimes the failure of the protagonists, who are subject to the forces of history, culture and power relations, to fulfill their dreams. As cultural mediators, both writers attempt to diagnose the "maladies" hindering cultural interaction or the formation of the protagonist's identity. Meanwhile, the protagonist's strife to carve an identity for himself/herself and inhabit a "third space"/"contact zone"/"mezzaterra" and his/her initiation into the host society render the stories as bildungsroman. According to Mark, the Bildungsroman "narrates the acculturation of a self - the integration of a particular 'I' into the general subjectivity of a community, and thus, finally, into the universal subjectivity of humanity" (38). Postcolonial writers, too, employ the Bildungsroman. They

reshape the story of education as one of becoming alienated subjects of double legacies in ways that interrogate the form's ideology of development, self-determination, and incorporation of citizens into the new nation. (Smith and Watson 129)

Furthermore, as postcolonial short stories, they are concerned with issues such as hybridity, alienation, third space, diaspora, identity formation and cultural encounter. The stories present a critique of the experience of the immigrant going through the process of cultural transformation from the writers' perspectives. In analyzing the "maladies" or problems hindering cultural interaction/exchange, both writers are keen on showing that sometimes the immigrants themselves are responsible for these problems not only the host society. Therefore, the failure of cultural interaction may not be only caused by the differences between two cultures but also among the members of the same culture.

The failure of communication among the members of the same culture is shown as one of the great maladies distinguishing postcolonial, transcultural world. It results in severe cultural and psychological displacement. Whereas Soueif's "I Think of You" (1996) and Lahiri's "Interpreter of Maladies" (1999) are examples of a failure in cultural communication, "Melody," by Soueif, and "The Third and Final Continent," by Lahiri, present positive cultural experiences inhabited in the "third space," "contact zone" or "mezzaterra."

An embodiment of transcultural experience, the protagonist of the autobiographical "I Think of You" ("ITY") - published in the collection of short stories entitled Sandpiper in 1996 - is an upper class Egyptian woman who has gone through the East/West cultural encounter with great success but who failed to overcome the cultural disparities inherent in her 
own native culture. A university professor, the unnamed protagonist is married to an English man and has a five-year-old daughter. She lived in England with her husband and daughter before she moves to a Gulf country where she works as a university professor. Due to medical problems, the protagonist is forced to stay in a hospital, until she gives birth to her second baby. Separated from her English husband, her daughter and family, the unnamed protagonist/narrator feels deeply alienated and culturally displaced in the hospital, though she shares the same language and culture with other Arab patients. Embedded within the main story is that of the protagonist's ill friend, Nihad Gad, who died of cancer and for whom Souief dedicates the story. Unable to adapt to her present predicament, the protagonist resorts to her memories as a refuge in order to establish human contact with her now deceased friend. It is the experience of pain and suffering that unites them.

Conceiving the Arab world from her own perspective, the unnamed narrator's attitude towards the Arab women staying in the same hospital with her, and who are always shown wearing the veil, reflects the binary opposition between the civilized Western world she thinks she belongs to and the typical Oriental one she is forced to live in. A comparison is always made between both worlds. For example, she and her sick friend, whom she remembers now, are compared with other patients:

Barbarian Queen, I thought then, Medieval Matriarch. Now, beached in this strange country, I wonder what these women amongst whom I find myself would make of you. Five women, each in a bed. They are dressed in greys and browns; garments fashioned so that underneath them they are all identical, solid bulk. Their hair is closely wrapped in dense black cloth, and more black cloth is folded back on top of their heads ready to veil their faces at a second's notice. My white cotton night-dress, smocked, buttoned to my throat, wide-sleeved with a frilled cuff touching the backs of my hands, feels light, revealing, beside the dark layers that they wear. My hair is uncovered and loose. ("ITY" 132)

The significance of the narrator/protagonist's words is twofold. They reflect the inner conflict within the protagonist's psyche. The choice of the words "beached in this strange country" clarifies her suffering as she is forced, because of her work and her illness, to remain in a "strange" country with no hope of escaping. The use of the word "strange" is ironic as she actually lives in an Arab country. In other words, the fact that she shares the same language and culture should have created more affinities and established a better communication with them. In addition, they 
establish the East/West dichotomy reflected in the differing cultures adopted by the protagonist and her friend, on one hand, and the veiled women, on the other. Seen from the narrator's perspective, the veiled women are typical representatives of Orientalist world. The fact that they are unnamed throughout the story reflects their marginalization. They are submissive to the rules set against them by their patriarchal society. They are imprisoned within tradition and religious culture that deny them their basic human rights. They are not allowed to speak to, be seen or heard by foreign men. They are forced to wear the veil:

the door of the ward swings open, a warning cough is heard, and a man walks in. Four hands fly up to four heads, four veils drop over four faces, and all sounds cease. Heavily I stand and reach for the curtains as the man, with lowered eyes, walks to the fifth bed and sits by his wife. ("ITY" 133)

What intensifies her suffering, besides her illness, is that she is forced like other patients - to submit to the same rules of oppression in the hospital:

I am not supposed to move, not supposed to move at all. But I walk slowly around my bed, drawing the green and yellow curtains, plucking at their edges, placing them carefully one over the other to complete my isolation. [...]. I feel the tears well into my eyes and let them trickle coldly down my temples and into my hair. I do not want to be here. ("ITY" 133)

The writer does not only criticize the Arab society for suppressing and marginalizing women, but also for nourishing stereotypical notions about the West as well, another malady which inhibits the East/West communication. The following dialogue between the protagonist and another woman who wonders how the protagonist married an Englishman substantiates for this idea:

"How can you live there? They are all animals there."

"They are people, like us."

$[\ldots]$

"Among them there is good and there is bad."

"They copulate on the streets there." [...]

"I have lived there a longtime. I never saw anybody copulating on the street." 
"I saw it",

"Where?"

"In films. My husband brings home video films and I have seen them." $[\ldots]$

"Films don't represent the truth." ("ITY" 143)

Ironically, in their perception of each other, both the East and the West create a negative image of the Other. The effect of the media as the only source of knowledge maintained by the majority of people is apparent here. Similarly, the West is seen as having the same misconception about the Other. The Scottish nurse also sees the Arabs as "animals:" "They are animals these people," she says, 'animals.' "They don't understand a thing. They think if they have rules it makes them civilized" ("ITY" 144). Whether the word "animals" denotes sensuality or "barbarity," it reflects the adherence to certain fixed notions about the Other. It is thus impossible for either the East or the West to inhabit a common ground. In this way, "I Think of You" condemns the adoption of stereotypical notions or images about the Other which are advocated by the hegemonic discourse of the Arab culture. The story also explores the formation of the Egyptian woman's hybrid identity that had access to both Arab and English cultures and was able to negotiate and form a new identity for herself. Coming back home, the protagonist's hyphenated identity is challenged to reconsider the inward tensions within the native culture. The story shows that the protagonist is partly responsible for the lack of meaningful communication with her Arab society. As she symbolically draws the curtains separating her bed from the other patients, the protagonist actually imprisons herself within the walls of her own world seeking refuge in her past memories with her sick friend and her tears. She establishes a high wall against any communication.

Soueif also criticizes the duality and religious pretention prevalent in Muslim society which impedes communication among the Arabs themselves. Seen as a stranger, a foreigner, the unnamed protagonist is subject to sexual harassment in a phone call by one of the doctors working in the hospital. Ironically, he speaks English during the phone call as Arabic will uncover his true identity. Ironically, too, the protagonist observes a note put between the TV and the window which states that "Under no circumstance you must be alone with male doctor. Call sister urgently if male doctor approaches you for examination"("ITY" 139). By showing the contrast between the "note" which is informed by religious teachings and the doctor's behavior, the writer lays bare the discrepancies and contradictions inherent in Muslim 
communities. However, Soueif's unmasking of this religious duality should not be perceived as rejection of Islam itself which is allegedly conceived to be against women. In this context Malak states:

One cannot disavow or condemn the entire culture of Islam, in whose name several cruel practices are done against women. This attitude in Soueif's writing is a shared feature with the works of other Arab and Muslim writers in English that reveal an unequivocal sense of affiliation with their Islamic culture, while at the same time condemning and combating the abusive excesses of patriarchy when it appropriates and exploits the religious argument to preserve its own spiritual and material hegemony. (129)

By delineating the protagonist's cultural experience in the Gulf country, Soueif shows her protagonist's inability to come to terms with her own culture. Despite the fact that she speaks the same language and shares the same culture, the protagonist fails to create a "mezzaterra" in her new milieu. The writer thus shows that it is necessary to resolve all the tensions resulting from cultural and religious barriers instead of condemning the West/East for creating misconceptions or stereotypical images about each other. As interpreter of her native culture's maladies, Soueif, in "I Think of You" ("ITY"), shows that the basic problem hindering cultural exchange lies in the inner social and religious tensions within the East. According to Soueif, in order to establish a better communication with the West, the East must settle its own dichotomies and resolve its internal conflicts first. In reconstructing the Eastern identity, the writer suggests that the Eastern world should learn how to transcend and negotiate the tensions arising from religious or cultural differences that lead to incomprehension of the Other.

Like Soueif's "I Think of You," Lahiri's "Interpreter of Maladies" ("IOM") (1999), shows, as Sahu puts it, "the pattern of hope and disenchantment arising from the predicament of the writer placed between two traditions, neither of which she can wholly accept or renounce" (106-107). Like the other short stories in the collection, Lahiri's "Interpreter of Maladies" delineates how "the English culture produces disenchantment in the minds of the expatriate Indians, and how they find themselves crushed under the burden of alienation and rootlessness" (107). The protagonist of Lahiri's "Interpreter of Maladies," Mina, is a second generation Indian woman living in America. Mina is married to Mr. Das and has three children. Together, they decide to spend their summer vacation in India. However, Mina is not enthusiastic about 
the visit. The short story depicts her feeling of alienation and cultural displacement not only in her native country but also with her own family.

Throughout Mina's character, Lahiri deconstructs the essential representation of the Indian woman as a faithful wife, a devoted mother and a silent sufferer. Rather, Mina is a symbol of the "new woman." Though she married Raj Das, the childhood friend, whom she used to love, she was forced to leave her friends at college and remain at home to perform the fixed role of any Indian wife and take care of her family instead of pursuing her career as a free individual: "she was left at home all day with the baby, surrounded by toys that made her trip when she walked or wince when she sat, always cross and tired" ("IOM" 64). Frustrated, she wants to "throw everything I own the window, the television, the children, everything" ("IOM" 65). Caught between her attempt to adopt the American norms that stress individuality, freedom and equality and her native cultural affiliation that entraps her within the fixed role of mother/wife, she is unable to resolve that tension and finally betrays her husband.

The reader is further introduced to Mina through the gaze of Mr. Kapasi, the tour guide the Das meet in India:

He observed her. She wore a red-and-white checkered skirt that stopped above her knees, slip - on shoes with a square wooden heel, and a close - fitting blouse styled like a man's undershirt. ("IOM" 46)

Mina's physical appearance, from Kapasi's perspective, reflects her foreignness. For Kapasi, the Dases "looked Indian but dressed as foreigners" ("IOM" 43-44), and he, Kapasi, was "accustomed to foreign tourists" ("IOM" 45). Mina cannot understand Kapasi's native culture or language. She did not express any "irritation, or embarrassment, or react in any other way" to the Indian song of the shirtless Indian man, probably because, according to the narrator/Kapasi, "she did not appear to understand the words of the song" ("IOM" 46). Cultural differences are even manifest in the way both Das and Kapasi greet each other:

When he'd introduced himself, Mr. Kapasi had pressed his palms together in greeting, but Mr. Das squeezed hands like an American so that Mr. Kapasi felt it in his elbow. Mrs. Das for her part had flexed one side of her mouth smiling dutifully at Mr. Kapasi, without displaying any interest in him. ("IOM" 44) 
The Dases are not emotionally interested in or related to their native country. They are even indifferent to scenes of poverty around them. As a foreign tourist, Mr. Das stops to take a photo of a "barefoot man, his head wrapped in a dirty turban" (IOM" 49). He also takes photos of monkeys which are "more hungry than dangerous" ("IOM" 61), like the other poor Indians they come across. It is the colonizer's gaze into an exotic place that marks the Dases' visit to India.

Unlike the stereotypical representation of the immigrant who suffers from nostalgia, Mina is disinterested in her visit. As a foreigner, she is dissatisfied with the heat and sights of her country. Instead of walking into the temple with her family, she prefers to stay in the car. She is also depicted as a careless and disinterested mother. When her daughter asks her to paint her finger nails, she scolds her: "leave me alone" ("IOM" 48). When her husband asks her to take their daughter to the toilet, she declines to hold her daughter's hand while walking to it.

As a transcultural fiction protagonist, Mina, in her visit to India, which is a journey towards self-discovery, failed to reconcile herself to her native Indian culture. Furthermore, her experience in India - which recalls that of the protagonist of Soueif"s "I Think of You" in the Gulf hospital - only intensifies the conflicting forces within her psyche and confirms her cultural displacement. Moreover, Kapasi's failure to interpret the pain and loneliness Mina feels widens the gap between them. For her, he becomes a symbol of traditional patriarchal authority that undermines her agency. Though admiring Mina as a representative of the New Indian woman, Kapasi, for instance, rejects her once he knows about her illegal affair. Also, he fails to resolve her doubts about the validity of their cultural norms. Mina thus rejects the forces of history, culture and male authority that imprison her within the fixed mother/wife identity. Mina's cultural encounter with Kapasi, in addition, reflects the continuous change within cultural identity which is in a perpetual state of "becoming," to use Hall's concept. It also shows that the hybrid identity can no longer integrate within his/her native culture - which is also evident in Soueif's "I Think of You." The journeys of both Soueif and Lahiri's protagonists were not, in this way, a homecoming but a chance to reconsider their cultural affiliations and resolve their doubts. The journeys also unmask the paradoxes within the Muslim and Indian societies.

Depicting the experience of cultural encounter which, as Bhabha describes, is in flux and unstable, "Interpreter of Maladies" reveals the complexity of its representation. The experience provides both Mina and Kapasi with rare moments of recognizing each other. Interpreted in terms 
of Pratt's concept of the "contact zone," Mina's cultural encounter shows the clash of her hybrid identity with her native culture. She rejects Kapasi's male dominance and his attempt to interpret her feelings of frustration and isolation as guilt. The reader, in turn, is invited to reconsider this encounter from a different perspective and question the long adopted notions about fixed identity or culture. Diaspora is seen as a malady that results in a lack of communication and incomprehension among both Arabs and Indians in Soueif's "I Think of You" and Lahiri's "Interpreter of Maladies."

The subtitle of "Interpreter of Maladies," "Stories from Bengal, Boston and Beyond," reflects the main issue of the story, i.e. the characters' attempt to cross cultural barriers. Though Kapasi and Mina share the same native culture and can speak English and suffer from similar marital problems, "the bickering, the indifference, the protracted silence" ("IOM" 53), they fail to go "beyond" their cultural differences. The story suggests that a "third space" is not only needed to be established between differing cultures but also among the members of the same culture, an idea which the writer herself confirms while describing Kapasi's illusions about his job:

The job was a sign of his failings. In his youth he'd been a devoted scholar of foreign languages, the owner of an impressive collection of dictionaries. He had dreamed of being an interpreter for diplomats and dignitaries, resolving conflicts between people and nations, settling disputes of which he alone could understand both sides. ("IOM" 52)

Ironically, he fails to interpret or communicate with Mina who belongs to the same culture. His dream of being "an interpreter between nations" ("IOM" 53) is destroyed. The narrative also discloses his limited vision. His knowledge of American/Western culture - like that of the unnamed woman of Soueif's "I Think of You" - is based on what he sees on television, particularly the Dallas Show.

In her essay "Intimate Alienation: Immigrant Fiction and Translation" (2002), Lahiri argues that most of her characters are translators "in so far as they must make sense of the foreign in order to survive" (120). Viewed in Lahiri's terms, both Kapasi and Mina fail to translate their experience. As cultural mediators, their encounter uncovers the paradoxes inherent in the process of cultural exchange. Kapasi's hope that "all of life's mistakes made sense in the end" ("IOM" 56) turns out to be a mere illusion. 
It is remarkable that despite the feminist overtones of the story and the class differences between Mina and Kapasi, the resulting incomprehension between them, according to Lewis, is due to cultural rather than racial differences. He argues that

Lahiri moves beyond Eurocentric or Orientalist images of India to those of a contemporary postcolonial nation more concerned with dialogue with its own diaspora than with its former colonizer. The story may repeat the Forsterian theme of mutual human incomprehension, but the world of "Interpreter of Maladies" is an exclusively Indian one in which Indians move freely among countries and cultures, and in which India itself is an object of scrutiny by Indian eyes. (219)

Lewis suggests that though Lahiri's story reworks Forster's theme, it "denies that the malady that comes between people has its origin in race or geographical location," thus exposing "the outdated racialism of Forster's novel" (221), hence the significance of the subtitle of the story "Bengali, Boston and Beyond." In other words, Lahiri suggests that the obstacles hindering cultural exchange for those inhabiting the "third space" or the "contact zone" go beyond colonial racism or gender.

In their portrayal of the maladies hindering cultural communication, both Soueif, in "I Think of You," and Lahiri in, "Interpreter of Maladies," make use of various technical devices. To begin with, Soueif's "I Think of You" is distinguished with its myriad techniques. The use of the first person narrative reflects the isolation and estrangement the protagonist feels in the hospital. In addition, it shows that her judgment on the world around her is limited to her own perspective. The story is also marked with its classical structure. The unities of place and action are observed. However, action is often interrupted to give space to the protagonist's past memories to flow into the present as usually done in the stream of consciousness novel. Time moves forward and backward through the use of flashback. The story is also marked with the technique of embedded narratives. Thus, the main story of the protagonist intersects with that of her dear friend. Both are alienated by their illness:

My mother phones and tells me you have been to America and back and no, you are not better. Do you think of death? You must do. You must know you are dying. Half your stomach taken out, the needle plastered to your hand ready for your next feed. Your brother scouring the medical depots 
for supplies, your doctors on twenty- four- hour rotas, your family coming and going and no one ever mentioning the dread name of your disease. ("ITY" 145)

The interior monologue becomes the protagonist's main solace as she cannot establish a meaningful dialogue with the other patients in the hospital. It also reflects her feeling of estrangement and own inability to adapt to her present situation:

What will they think when they come in and find me like this: a suffering figure, arms stretched out the sides? Or do Christian images - even this one - not exist for them at all? They are probably not into images. Our religion is a religion of the Word not Image. I close my eyes. ("ITY" 139)

The use of colours also reflects the protagonist's state of mind. The whole world seems to be affected by her friend's illness. It has turned black: "Through the window, the darkness of Cairo night was so intense; it seemed that if I reached out my hand I would touch black velvet" ("ITY" 131). In addition, the description of her ward with its dominant colours, white and grey, and the description of the Arab women patients who are also dressed in black or grey with nothing to show except their eyes help to increase the protagonist's feeling of alienation and depression besides confirming the one-dimensional perspective of patriarchal society that considers women invisible, silent objects.

On the other hand, despite her criticism of the inner maladies within the Arab society, the protagonist/writer does not wholly denounce or renounce her cultural roots. In spite of the fact that the story is written in English, certain Arabic and Egyptian words are fused to reflect the writer's bicultural and bilingual nature. For example, references are made to the "tarha" of her friend's nanny, and the "consultant, majestic in his white robes and black-and-gold abaya"("ITY"140). Arabic phrases that have religious connotation in Islam are also used. The following dialogue between the protagonist and a woman who brought her a dish is a clear example:

"Peace be upon you!"

"And upon you, peace and the mercy of God and

His blessings." [...]

"I have brought you something to support you, sister. Hospital food is tasteless." 
"May God increase your bounty," I say; "it was not necessary to trouble yourself." ("ITY" 142)

It is clear that this dialogue is taken from Arabic cultural discourse, the significance of which can be easily grasped by an Arabic reader rather than an English one.

The writer uses satire to unravel religious pretension and the duality within Muslim society. The contradiction between the instructions written on the note put between the TV and the window in the ward, which says: "Under no circumstance you must be alone with male doctor. Call sister urgently if male doctor approaches you for examination" ("ITY" 139), and the phone call made by the doctor who uses the English language to hide his Muslim identity to make an illegal relationship with the protagonist is a case in point. The writer also allows other voices to express themselves, a device which renders the text polyphonic. The dialogue between the narrator and one of the women in the hospital and the narrator and the Scottish nurse concerning the East/West perception of each other as "animals" is important to signify the roots of the clash of cultures.

Unlike Soueif's "I Think of You," Lahiri's "Interpreter of Maladies" is rendered in the third person narrative which sometimes shifts to the first person. The complexity of representing cultural experience is revealed through the varied perspectives of the narrative. Both Mina and Kapasi present their experience from their own perspective. The different perspectives/voices reflecting the forces affecting their identities reveal the polyphonic nature of the story. In reconstructing her own diasporic identity, Mina has to rebel against the traditional roles assigned to her as an Indian wife or mother. She aspires to gain her freedom as an American woman. She is not interested in regaining her cultural roots. She is also disappointed when Mr. Kapasi fails to appreciate her suffering. Mr. Kapasi's character also reveals similar conflicting voices. Like Mina, he is frustrated with his marriage. He wishes to accomplish his dream of being an interpreter between nations. His arrogance and vanity blind him to see the wide gap between Mina's cultural background and his own. His naivety is also apparent in assuming that human contact can resolve all problems or that Mina admires him only to find out that true human communication is sometimes unattainable. 
"Interpreter of Maladies," unlike Soueif's "I Think of You," follows a linear narrative structure. It begins with a common exposition in which the Dases are introduced to the reader both outwardly as well as inwardly. The apparent failure of the Dases' marriage, their cultural displacement and inner conflict of Mina offer a deeper exposition of their consciousness. The inability of Kapasi to identify Mina's malady reveals the dramatic irony of the narrative, i.e. though belonging to the same culture and speaking the same language, both Mina and Kapasi fail to establish a "third space" or transgress their cultural differences.

The title of the story is symbolically significant. In one of her interviews, Lahiri says that she chooses the title of the story as the main title for the collection because it best reveals "the predicament at the heart of the book - the dilemma, the difficulty, and often the impossibility of communicating emotional pain and affliction to others, as well as expressing it to ourselves" (qtd. in Dalton-Brown 344). In fact, it is the difficulty not only of expressing pain but also of representing it that marks "Interpreter of Maladies" as a postmodern short story.

Whereas both "I Think of You" and "Interpreter of Maladies" represent unsuccessful attempts at inhabiting the "third space"/"contact zone"/"mezzaterra," Souief's "Melody" and Lahiri's "The Third and Final Continent" provide positive examples of cultural exchange. In "Melody," Soueif advocates the possibility of transcending racial and cultural barriers and inhabiting a "mezzaterra." The story depicts the life of characters belonging to different cultures - English, Egyptian, Turkish, Lebanese, Scots, etc. - who are forced to live in one place: the compound. The narrator, an English woman who is married to Rich and has a child, Wayne, shares a compound with a group of other women. We are introduced to Ingie, the Turkish woman who is married to an Egyptian. She has two children: Melody and Murat. The narrator also has a Scottish friend, Elaine, who is also married and has a child. Other inhabitants of the compound include a Lebanese flower-man, Egyptian, German and Filipinos neighbours.

Though narrated in the first person, the story is more concerned with depicting the experience of Ingie who lost her child, Melody, in a car accident. This experience of loss brings about the common affinities shared by the inhabitants of the compound. Ironically, the death of 
Melody has fulfilled a prophecy Ingie heared in the past. She tells the narrator that "she did not want to get pregnant because some fortuneteller back home said that she would have three children and one would break her heart. So, she figured if she only had two, that would somehow invalidate the whole prophecy" ("Melody" 9). So, from the early beginning of the story, the reader can feel the tragedy hovering over Ingie and her family. The story shows how Ingie used to be a "very joyful person" ("Melody" 7) before the death of her daughter: "when you visit her she always has some tape on-loud. Disco, rock, oriental music, whatever" ("Melody" 7). She is very kind to her neighbours. She helps Wayne to pick his gun when it dropped into the pool. She allows him to play with Melody at her house. Her main thought is "laughing. Laughing and clothes and make-up and dancing" ("Melody" 6). When the narrator and her family moved in, Ingie brought them a present: "When we first moved in, she would come around, may be twice a week, each time with some 'little thing' she had made: pastry, apple tart, pizza, whatever, things that take a lot of making" ("Melody" 8). Though she is culturally different from the narrator and despite her bad English, "her English is appalling" ("Melody" 5), both Ingie and the narrator mange to communicate with each other. Though Wayne, the narrator's son, cannot understand much of Murat's words, he prefers to stay with Melody all the time. The narrator recounts that one day Melody

was supposed to be coming to our apartment to play with him and she did not. He just sat and waited. He wasn't even four yet but he sat and waited for her for over two hours and then he made me take him to Ingie's apartment and when they weren't there he sat down on the doorstep and wept. This whole compound, as far as he was concerned, was 'where Melody lives.' ("Melody" 8)

The whole compound was a heaven to Ingie, the devoted wife and the kind mother. Ironically, the prophecy was finally fulfilled. Ingie's heart was broken. The joy and happiness that characterize her nature have turned into grief. Describing the mourning mother, the narrator says:

I was all ready to find that she had aged overnight. But she hadn't. She seemed, if anything, younger. She had lost a lot of weight. I don't know how she managed it in only twentythree hours but she had and she looked slight and frail in her long black skirt and her black T-Shirt. No make-up, her hair pulled back and knotted with a rubber band, black circles 
around her eyes. Her skin-not just the skin of her face but of her arms, hands and feet, all you could see of her-had grown finer: almost transparent. ("Melody" 11-12)

Cultural or religious barriers have vanished in Melody's funeral. Though culturally displaced, the characters find common bonds that gather them, i.e. their humanity:

The apartment was full of women. Women and babies. Women sitting. Women making coffee. Women preparing food and handling it to the men outside. One woman was doing the dishes. Another was folding up some dry washing. All the women were in black. ("Melody" 11)

All have come to console Ingie in her distress. Even men, who are strongly criticized in this story for oppressing and manipulating women, came to Ingie's help. The Lebanese flower-man rushes to help Melody. He takes the poor girl to the hospital. His clothes are covered with her blood.

Though Melody's murder brings about the best in human nature sympathy, compassion and solidarity - among Ingie's neighbours, it reveals the worst in her father's nature. He blames Ingie for the death of their child and informs her to give him a third child instead. His cruelty and inhumanity is revealed when he films the dead child in the morgue and the place of the accident. He makes interviews with the flower-man and the eye witnesses. Elaine tells the narrator what he did:

He sat Ingie down and made her watch both his films: the one on the road and the one in the morgue. And he made her watch the film of Melody's last birthday. He said what happened is her fault and she has to be made to feel it. ("Melody" 17)

Moreover, he informs his wife that she "is not allowed to take little Murat out at all because he can't trust her to look after him" ("Melody" 17).

Melody's father gives himself the right to punish Ingie because he is a man. Men, in Soueif's story, are allowed to do anything. For example, they are allowed to use the pool because they are men and "they can use anything. And they do" ("Melody" 3). Unlike men, women are not allowed to enjoy their life. Ingie's husband was married to an American woman and lived in Denver for twenty years. Elaine tells the narrator that "they had two boys and he looked after them and did everything else as well. The wife worked and she had, like, a strong personality and naturally she wouldn't do anything in the house" 
("Melody" 6-7). When he married Ingie he treated her as a typical Orientalist husband. She is even blamed for the death of their child. She has to spend the rest of her life suffering from that deep sense of guilt. Ingie, too, is a stereotypical Muslim wife and mother though she likes music and dancing. Her identity is totally suppressed by her husband who symbolizes male dominance.

The writer's rejection of male dominance is not only directed against Muslim husbands but is enlarged to include all men in general. Like Ingie, the narrator herself is the second wife of her English husband who had three other children by his first wife. In order to have a child of her own, the narrator agreed to come and live with him in this compound. However, once she conceives Wayne, the husband "really chickened out and went and got himself vasectomised so I could not nag him for another kid" ("Melody" 8-9). It is the male who always determines how things should run. Ingie is afraid her husband would know that she is "on the Pill" ("Melody" 9). She hides the strip "among Melody's pants and vests and terrified that he should find out" ("Melody" 9). The writer makes it clear that the reaction of Ingie's husband is typical of all Muslim men: "That's what these Muslim men are like, they can never have enough children. Mostly though, they want boys" ("Melody" 9).

The gloomy image of the male/female relationships depicted in the story is typical not only of the Oriental society but is also prevalent in the Western one - as the story shows. In both cultures, women are subject to men's whims. They are silent sufferers, victims of men's dominance. However, despite its tragic tone, the story presents an optimistic vision of the possibility of establishing a "mezzatera" among the inhabitants of the compound. They manage to cross cultural barriers among them by enhancing their human affinities or commonalities. It is the shared human values that can transcend cultural, political or racial differences.

The same optimistic tone is conveyed in Lahiri's "The Third and Final Continent" ("TFC") (1999). The short story narrates the successful journey of an unnamed first generation Indian immigrant across three continents - India, Europe and finally America - until he becomes an American citizen. Moving from India on an Italian ship in 1960s, the narrator spends some time in England where he lives in a flat with other "penniless Bengali bachelors" ("TFC" 173) before he finally settles in America where he works at a library in Massachusetts. Like most Indians, his own marriage was arranged by his family. The story depicts the first six weeks of the narrator's life in America before his wife joins him. Renting a room in Mrs. Croft's house, the story then shows the growing relationship between the immigrant and Mrs. Croft. The initiation of the 
narrator into the American society, his struggle to assimilate and adapt to American life and negotiating his identity between his native culture and that of the host society until he manages to become an American citizen renders the short story a perfect bildungsroman.

The relationship between Mrs. Croft and the unnamed narrator/protagonist is a metaphor of the East/West cultural encounter. Depicting the various stages of the immigrant's initiation experience, the story shows, for example, how Mrs. Croft, at the beginning, assumes the role of the superior colonizer who forces her subject to comply with her rules as a tenant. She always speaks in a commanding spirit. She looks fierce and talks in a very loud voice. The immigrant should not deal with her directly. Rather, he is ordered to lock the entrance door and fasten the chains, or as she puts it, "this is the first thing you shall do when you enter, is that clear?" ("TFC" 179). He will not give her the money in her hand. Rather, he should put it on the lodge.

Mrs. Croft's physical description reveals her nature. She wears a long black skirt and a white shirt edges with ruffles at her throat and cuffs. Refusing to live in the $20^{\text {th }}$ century, she has created a world of her own choice and locks herself in a world of her own. Caesar remarks that Mrs. Croft

locks out a world she no longer understands, and these locks make her feel secure. She apparently never leaves the house, but she is certainly not a prisoner there. Rather, she controls her contact with the outside world by letting in boarders she approves of and by reading and listening to the radio. She controls both her boarders and her borders. The walls of her house are the walls of the self, but it is an integrated and contained self that takes in what it needs from the outside world-her daughter, news, her boarders. ("TFC" 53)

Like Mrs. Croft, the unnamed narrator chooses to lock himself in his room. Caesar also assures that

the narrator lives behind locked doors of his own, walls within his mind that shut out an inner world of death and insanity. The world that he is successfully running away from is represented by the ancestral home to which he takes his wife Mala and in which he cannot love her. ("TFC" 54)

Both Mrs. Croft and the unnamed narrator lock themselves from the real world. Rejecting the American world of the $20^{\text {th }}$ century, Mrs. Croft chooses to live in the Victorian age, the world of propriety and moral 
standards. Similarly, the narrator locks himself in a world of his memories: his mother's illness, her suffering and death as well as his forced marriage. He admires Mrs. Croft for her strong will and independence. Unlike his mother who died of grief over her dead husband, Mrs. Croft overcame her crisis, raised her children and lived until she was 103 years old.

Gradually, both Mrs. Croft and the narrator develop a meaningful human contact. Both, in Caesar's terms, "enact the conventions that connect them. The conventions are not empty formulas, but ways of a acknowledging and respecting one another's humanity"("TFC" 55). Metaphorically, this "mezzaterra"/"third space"/"contact zone" occurs when, to use Caesar's words,

he puts the rent directly into her hands rather than placing it on the lodge as she had asked. He understands that the eightdollar rent is merely a gesture, an assertion that this is her territory like the flag on the moon. She rents the room not for the money, but for the excuse it provides for human contact on her terms. Giving her the money directly is an acknowledgement that he is paying her, another human being, for the right to live in her house and it is a human contact, impersonal, but human. ("TFC" 55)

It is clear that the cultural encounter experience between the immigrant and Mrs. Croft is beneficial for both of them. It forces Mrs. Croft out of her solitude. The immigrant's persistence, perseverance, politeness and respect help her to change her pre-determined postcolonial attitude. She begins to appreciate his care, kindness and good behavior as indicative of a true man of honour. In fact, their cultural experience is marked by mutual cultural transformation. Their identities have changed in turn. Both manage to cross cultural, racial and class barriers and create a third space for themselves. Both have acquired a third identity. Once Mrs. Croft sees Mala, the immigrant's wife, she does not disregard her for her weird dress or different culture. Rather, she sees her as "a perfect lady" ("TFC" 195), i.e. a human being worthy of respect. It is also remarkable that both Mrs. Croft and the narrator/immigrant recognize each other's difference and also enhance their sameness or "commonalities," to use Welsh's words, or "affinities," to use Soueif's words.

The success of their cultural experience is a metaphor of the immigrant's experience in diaspora in general. Both Mrs. Croft and the narrator have been cultural translators/mediators between the East and the 
West. They affect each other in one way or another. The narrator acknowledges that "I knew in my heart one day her death would affect me, and stranger still, that mine would affect her" ("TFC" 195). She has become another mother to the narrator. He greatly respects her. Similarly, she tells her daughter that the immigrant is "a gentleman" and "very kind," an indication of the growing intimacy between them.

Though she appears late in the story, Mala's character is first drawn as a stereotypical Indian wife. However, she is well educated. She can also "knit, embroider, sketch landscapes and recites poems by Tagore" ("TFC" 181). To stress her identity marker, Mina uses Indian recipes for her food and cooks Indian meals and wears the Indian sari, which reflect her longing for her cultural roots. However, she also manages to assimilate the American culture.

The relationship between Mala and her husband reflects the development of their characters. Forced to marry Mala, the narrator only remembers that he spent their wedding night in his deceased mother's room. Mala reminds him of his suffering when he was forced to take care of his insane and sick mother. When Mala joins him in America, he could not force himself to love her. However, the visit both the narrator and his wife pay to Mrs. Croft marks a turning point in the development of their relationship:

I like to think of that moment in Mrs. Croft's parlor as the moment when distance between Mala and me began to lessen, although we were not yet fully in love, I like to think of the months that followed as a honeymoon of sorts. Together we explored the city and met other Bengali, some of whom are still friends today. ("TFC" 196)

Once she sees Mala, Mrs. Croft admires her long dress and propriety which reminds her of the old Victorian values. A symbol of Indian culture, Mala is seen as "a perfect lady" ("TFC" 195). The fact that she is accepted and welcomed by Mrs. Croft/the West marks a great success for the narrator. His love for his wife grows.

The writer is keen on showing that though adopting the American life, both Mala and her husband grow tomatoes in their garden and travel to India. Their son is a student at Harvard. He comes home in the weekends and "eat[s] rice ... with his hands, and speak[s] in Bengali" ("TFC" 197). They meet other Bengali friends occasionally. Their life journey has fulfilled its mission when they become "American citizens[...] so that [they] can collect social security when it is time" ("TFC" 197). He passes by Mrs. Croft's house and narrates his story to 
his son. Such examples give clear evidence that the Indian family has succeeded to negotiate their cultural identity and establish a "third space" or "contact zone" by benefiting from both cultures. Similarly both Indian and American cultures overlap in that space without one culture assuming dominance over the other, as Soueif elaborates in her Mezzaterra.

The optimistic ending of "The Third and Final Continent" confirms the metaphor of America as a "melting pot" in which cultural differences melt away so that the true American spirit emerges. America has become a country for the immigrant and his wife who become American citizens. The optimistic ending of the story, which is actually the final story in Interpreter of Maladies, is intended by Lahiri to advocate the developing and nourishing of cultural exchange. The success of the narrator and his wife to negotiate their cultural identity in a diasporic community proves that cultural exchange is possible once all barriers are crossed.

Both "Melody" and "The Third and Final Continent" are distinguished by their narrative techniques. "Melody," for example, is rendered in the first person narrative. Events and characters are thus perceived from the narrator's own perspective. The story does not give chronological sequence of events. Rather, the action is sometimes interrupted through flashback to explain the present. Moreover, the story relies heavily on symbolism. The title of the story is symbolic of its tragic tone. Referring to the dead child, the word "melody," which means chanting or singing, reflects joy and happiness that characterize the life of Ingie and the whole compound before the accident. By the end of the story, it becomes a metaphor of the tragedy that besets the poor family. It is this "melody" that unites the different cultures of the compound together.

The setting of the story is a typical Oriental milieu which the writer delineates in a poetic language :

The scent of jasmine fills the air. It has been filling the air for the last month, I guess. Which is how you know the season is changing in this country. The bougainvillaea blooms against the walls all over the year round. The lizards dart out from under the stones and back in again. The mosquitoes buzz outside the netting and the pool-boy can be seen tending the pool every morning from eight to ten. ("Melody" 3)

In addition to creating a typical Oriental milieu (mosquitoes and lizards), the story employs "jasmine" as a recurrent motif that is associated with Melody. Despite its white colour and fragrance which reflect purity and 
innocence, the jasmine flower - as its Arabic meaning denotes - is also a symbol of despair. The life of Melody, furthermore, is as short as that of the jasmine flower. She only lived for fifty months. The narrator also remarks that after Melody's death "as I stepped out of the building the air seemed fresher and the scent of jasmine was even more strong. The children were still climbing the railings by the pool, buzzing with talk" ("Melody" 19), which suggests that life goes on despite its tragedy. The children, like jasmine, are symbol of innocence. They give life meaning and beauty even if they are short-lived.

Like Soueif's "Melody", Lahiri's "Third and Final Continent" relies on symbolism. Mrs. Croft's house is a symbol of America, the melting pot or the meeting point in which different cultures overlap and clash. Unlike the mainstream American fiction in which

the house is the self from which one must escape to discover the spirit of America, in Lahiri the house is where the spirit of America resides [...]. In addition, Lahiri moves beyond the metaphor that identifies growth with leaving what is known and shows that it is also rearranging what is known, as Mrs. Croft helps the narrator do with his perceptions of Mala and himself - and that it is accepting what is unknown, as all three characters do. (Caesar 58)

The setting of "The Third and Final Continent," symbolically signifies, to use Caesar's words, that "the solution to isolation is not outside, but within, in the re-vision of the self and the interior places of the spirit and in an imaginative sense of spatial connection to the place in which one lives" (58). In other words, it is the imaginative and figurative value of Mrs. Croft's house as a representative of "imaginative geography", to use Said's terms, that represents, for the Indian immigrant and his wife, a second home. Their feeling that America has become a second homeland marks the success and accomplishment of their life journey.

Realism is apparent in the setting of the story. The outward and inward description of Mrs. Croft's house also reflects its detachment or isolation from the outside world:

Next to the bench on which the woman sat was a small round table, its legs fully concealed, much like the woman's, by a skirt of lace. The table held a lamp, a transistor radio, a leather change purse with a silver clasp, and a telephone. A thick wooden cane coated with a layer of dust was propped against one side [...]. In the corner of the parlor I saw a grand piano with its top down, piled with papers. The piano 
is bench was wising; it seemed to be the one on which the woman was setting. ("TFC" 178)

The story is also distinguished by its interior monologue which reflects the protagonist's deep sense of alienation when he first arrived in America. Imprisoned within their experience, both Mrs. Croft and the narrator were busy with their memories rather than communicating with each other. Irony combines with the interior monologue to show the writer's sense of humor. The comparison the unnamed narrator made between his arrival to America and man's first landing on the moon, which significantly symbolizes his universal experience as Everyman, is a good example:

while the astronauts, heroes forever, spent mere hours on the moon, I have remained in this new world for nearly thirty years. I know that my achievement is quite ordinary. I am not the only man to seek his fortune far from home, and certainly I am not the first. Still, there are times I am bewildered by each mile I have traveled [sic], each meal I have eaten, each person I have known, each room in which I have slept. As ordinary as it all appears, there are times when it is beyond my imagination. ("TFC" 198)

In their exploration of important issues such as diaspora, cultural displacement, race, gender, etc., which affect characters, the short stories of both Soueif and Lahiri -selected in this paper - prove, as Hall states in "The Question of Cultural Identity," that

identities are never unified, in the late modern times, increasing fragmented and fractured; never singular but multiply constructed across different, often intersecting and antagonistic, discourses, practices and positions. (273-276)

The cultural transformation of the protagonists has been evident in depicting the various stages of their development. The focus on the experience of the immigrant in the host society, his/her attempt to overcome the several obstacles hindering his/her development, is a metaphor of man's struggle against the different forces undermining his agency.

In appropriating the language of the ex-colonizer, both Soueif and Lahiri write back to the dominant culture. Adopting strategies of appropriation is, as Ashcroft, Griffins and Tiffin remark,

the most powerful and ubiquitous way in which English is transformed by formerly colonized writers. Such strategies 
enable the writer to gain world audience and yet produce a culturally distinct, culturally appropriate idiom that announces itself as different even though it is English. (76)

As forms of resistance and imitation, hybridity and adaptation, the writings of both Soueif and Lahiri are narratives of the contact zone. As transcultural narratives, the stories depict the complexity of representing cultural encounters. Differences are negotiated from the protagonists' transcultural perspectives. Delineating the in-between dilemma, however, the writers also show their protagonists preserving certain features of their native cultures. The protagonists are shown as self-doubting characters whose cultural transformation disrupts dominant discourse and deconstructs essential or fixed notions of identity.

In fact, the binary opposition between the East and the West is not the main focus of Soueif or Lahiri's stories. Rather, both are more interested in the necessity of establishing a meaningful dialogue with the Other, be it the East/West or East/East cultures. Both writers are concerned with enhancing human commonalities, of enriching sameness rather than fostering differences. In other words, unlike the postcolonial hybrid that is forced to mimic the colonizer in order to be integrated within the diasporic community, the characters of both Soueif and Lahiri's stories are not forced to reproduce the dominant culture. Furthermore, they reconsider their own native culture and lay bare their inherent maladies which hinder internal comprehension among its members. Instead of nourishing feeling of nostalgia toward their native cultures, the protagonists/writers realize the complexity of their transcultural world and struggle to establish a common ground to communicate with the Other. Deconstructing old notions of fixed or essential identity, the development of the protagonists' identities shows them in a perpetual process of "becoming." In forming a third identity for him/herself, the protagonist does not have to go through the superior/inferior or dominant/submissive cultures conflict which marks postcolonial literature. Rather, the basic thing about the new established "mezzatera" is that all human beings are equal. Instead of nourishing dominant/submissive cultural egos, calls are raised to enhance cultural sameness, respect, natural understanding as well as other shared human values.

By uncovering the various maladies affecting and impeding cultural exchange, both Soueif and Lahiri call for a reconsideration of the general transcultural discourse in addition to questioning the stereotypical hegemony of this world culture. In exploring the complexity of representing the cultural encounter experience and the reconstruction of 
identity, both writers challenge not only patriarchal authority or dominant culture but also the dominant Western discourse.

\section{Works Cited}

Ashcroft, Bill, Gareth Griffins and Helen Tiffin. The Empire Writes Back. $2^{\text {nd }}$ edition. London \& New York: Routledge, 2002. Print.

Bhabha, Homi. "Cultural Diversity and Cultural Differences." The Postcolonial Studies Reader. Eds. Ashcroft, B., G. Griffins, H. Tiffin. New York: Routledge, 2006: 155-157. Print.

Caesar, Judith. "American Spaces in the Fiction of Jhumpa Lahiri." English Studies in Canada. Vol. 31, No. 1 (2005): 50-68.

Childs, Peter, R.J. Patrick Williams. Introduction to Post-Colonial Theory. London and NewYork: Routledge, 2013. Print.

Dalton-Brown, Sally. "The Freedom of the Inbetween: Gogol's Ghost and Jhumpa Lahiri's Immigrants". Forum for Modern Language Studies. Vol. 47, No. 3 (2011): 332-344.

Hall, Stuart. "Cultural Identity and Diaspora." Identity: Community, Cultural Difference. Ed. Rutherford, Jonathan. London: Lawrence \& Wishart, 1990. Print.

."The Question of Cultural Identity." Modernity in its Futures. Ed. Hall. London: Polity Press, 1999. Print.

Helf, Sissy. "Shifting Perspectives: The Transcultural Novel." Transcultural English Studies: Theories, Fictions, Realities. Amsterdam: Rodopi B.V., 2009: 3-36.

Lahiri, Jhumpa. Interpreter of Maladies. New York: Houghton Mifflin, 1999. Print.

. "Intimate Alienation: Immigrant Fiction and Translation." Translation, Text and Theory: The Paradigm of India. Ed. Nair, Rukmini Bhaya. New Delhi: Sage, 2002.

"My Two Lives." Newsweek. 6 March (2006). $<$ http://www.newsweek.com/my-two-lives-106355).

Maalouf, Amin. In the Name of Identity: Violence and the Need to Belong. New York: Arcade, 2001. Print.

Malak, Amin. Muslim Narratives and the Discourse of English. SONY Press, 2004. Print.

Mark, Redfield. Phantom Formations: Aesthetic Ideology and the Bildungsroman. Ithaca: Cornell University Press, 1996. 
Pratt, Mary Louise. Imperial Eyes: Travel Writing and Transculturation. London and New York: Routledge, 2008.Print. . "Arts of the Contact Zone". In MLA, Profession 91. NewYork: MAL, 1991: 33-40.

Said, Edward. Culture and Imperialism. London: Chatto \& Windus, 1993. Print. . Orientalism. Penguin Books, 1995. Print. . London Review of Books, Vol. 5 No. 12. 7 July 1983

<https://www.lrb.co.uk/.../edward-said-writes-about-anew-literature-of-the-arab-world. Jul 7, 1983>

Sales. Dora. "Living in a Transitional World: Translation as Part of Transcultural Identity." Transfer. VIII. 1-2 (Mayo 2013): 70-90.

Saha, Nandini. "The Nostalgic Note in Their Flute: A Reading of Arundhati Roy and Jhumpa Lahiri." Studies in Woman Writers in English. Vol. VI. Eds. Ray, Mohi Kumar, Rama Kundu. New Delhi: Atlantic Publishers \& Distributors (P) LTD, 2007.

Simon, Lewis. "Lahiri's 'Interpreter of Maladies'.” Explicator 59, 4. (Summer 2001): 219-21.

Smith, Sideonie, Julia Watson (eds.). Reading Autobiography: A Guide for Interpreting Life Narrative. University of Minnesota Press, 2010.

Sommer, Roy. Fictions of Migration. Verlag Tier, 2001. Print.

Soueif, Ahdaf. Sandpiper. London: Blommsbury, 1996. Print. . Mezzaterra: Fragments from the Common Ground. London \& New York: Bloomsbury, 2004.

Wassef, Hind. "The Unblushing Bourgeoisie.” Cairo Times. Vol. 2, Issue 5, 50 April, 1998.

<http://www.cairotimes.com/content/culture/suef.html>

Welsch, Wolfgang. "On the Acquisition and Possession of Commonalities." Transcultural English Studies: Theories, Fictions, Realities: 3-36.

Welz, Gisela, "Multiple Modernities: The Transnationalization of Cultures." Transcultural English Studies: Theories, Fictions, Realities: 37-74. 